\title{
PEMERIKSAAN SAKSI DALAM PERKARA PIDANA BERDASARKAN IUS CONTITUM INDONESIA
}

\author{
Toni Parlindungan S \\ Sekolah Tinggi Ilmu Hukum Padang \\ Email: gokmatoniparlindungan@gmail.com
}

Info Artikel:

Diterima: 19 Maret 2020

| Disetujui: 08 Agustus 2021 | Dipublikasikan: 12 Agustus 2021

\begin{abstract}
Abstrak
Proses pemeriksaan saksi dimulai dari penyidikan sampai pada tingkat penuntutan di pengadilan. Di tingkat penyidikan maka terlebih dahulu saksi diperiksa oleh penyidik dengan memperhatikan perlindungan terhadap saksi yaitu tanpa ancaman atau tekanan.dari pihak manapun. Kemudian saksi dapat diperiksa di tempat kediaman saksi dan saksi diperiksa tanpa disumpah. Sedangkan pada tingkat penuntutan atau pesidangan maka terlebih dahulu saksi dipanggil untuk didengar keterangannya. Penelitian ini bertujuan untuk memenuhi kebutuhan terhadap objek penulisan atau suatu karya ilmiah guna mendapatkan data-data, pokok-pokok pikiran, serta pendapat lainnya dari pakar atau media apapun, yaitu terkait pemeriksaan saksi dalam perkara pidana berdasarkan ius contitum indonesia. Dalam penelitian ini penulis menggunakan metode penelitian hukum normative.
\end{abstract}

Kata Kunci: Pemeriksaan, Saksi, Pidana

\section{EXAMINATION OF WITNESS IN CRIMINAL CASES BASED ON IUS CONTITUM INDONESIA}

\begin{abstract}
The process of examining witnesses starts from the investigation to the level of prosecution in court. At the level of investigation, the investigator first examines witnesses by paying attention to the protection of witnesses, namely without threats or pressure from any party. Then the witness can be examined at the witness' residence and the witness can be examined without being sworn in. Meanwhile, at the level of prosecution or trial, witnesses are first called to be heard. This study aims to meet the need for the object of writing or a scientific work in order to obtain data, main ideas, and other opinions from experts or any media, which is related to the examination of witnesses in criminal cases based on ius contitum indonesia. This research the authors use normative legal research methods.
\end{abstract}

Kata Kunci: Examination; Witness; Criminal 


\section{A. PENDAHULUAN}

Melihat Hukum Acara Pidana yang diatur dalam Kitab-Undang-Undang Hukum acara Pidana (KUHAP) mengatur tentang alat bukti yang diperlukan dalam penyelesaian suatu perkara pidana terutama dalam masalah pembuktian. Pembuktian adalah merupakan penyajiaan alat-alat bukti yang sah menurut hukum yang diperlukan pada saat perkara pidana disidangkan di pengadilan. ${ }^{1}$ Pengertian pembuktian yang terdapat dalam pasal 183 KUHAP adalah hakim tidak boleh menjatuhkan putudsan pidana kepada seseorang yang kecuali apabila sekurang-kurangnya terdapat 2 (dua) alat bukti yang sah dan ia memperoleh keyakinan bahwa suatu tindak pidana benar-benar terjadi dan terdakwalah yang bersalah melakukan tindak pidana. ${ }^{2}$ Dari penjelasan yang ada dalam KUHAP, maksud dan tujuan pembuktian adalah untuk menjamin tegaknya kebenaran, keadilan, dan kepastian hukum bagi seseorang.

Pasal 184 KUHAP menyebutkan tentang alat-alat bukti yang sah menurut hukum pidana yaitu: 1) Keterangan saksi; 2) Keterangan ahli; 3) Surat; 4) Petunjuk; dan 5) Keterangan terdakwa. Dari beberapa

1 Moeljatno, Asas-Asas Hukum Pidana, (Jakarta: PT Rineka Cipta, 2002), hlm. 67.

2 Sajtipto Rahardjo, Penafsiran Hukum Yang Progresif dalam Antony Freddy Susanto, Semiotika Hukum : Dari Dekonstruksi Teks Menuju Progresifitas Makna, (Bandung: Refika Aditama, 2005), hlm. 54. alat bukti tersebut maka terlihatlah bahwa keterangan saksi merupakan alat bukti yang utama dalam pembuktian kasus pidana disamping alat bukti lain. Keterangan saksi adalah sebagai alat bukti tentang apa yang ia saksikan dan dilihat atau didengar yang dinyatakan dalam sidang pengadilan. ${ }^{3}$ Satu keterangan saksi saja tidak cukup untuk membuktikan bahwa terdakwa bersalah dalam perbuatan pidana yang dituduhkan kepadanya.Keterangan tentang beberapa orang saksi yang berdiri sendiri tentang suatu kejadian atau keadaan dapat digunakan sebagai alah satu alat bukti yang sah apabila keterangan saksi itu ada hubungannya satu sama lain sedemikian rupa sehingga dapat membenarkan sahnya suatu kejadian atau keadaan tertentu. ${ }^{4}$

\section{Meneliti kebenaran tentang}

keterangan saksi hakim harus sungguhsungguh memperhatikan: ${ }^{5}$ 1) Persesuaian antara keterangan saksi yang satu dengan keterangan saksi yang lain; 2) Persesuaian antara keterangan saksi dengan alat bukti yang lain; 3) Alasan yang mungkin dipergunakan oleh saksi untuk membei

3 Sinta Agustina, Asas Legalitas dalam Tindak Pidana Korupsi, (Padang: dalam seminar Azas Legalitas dan Penemuan Hukum yang diadakan oleh Hima Pidana Fakultas Hukum UNAND pada tanggal 25 Maret 2010), hlm. 3. Jasmir, Pengembalian Status Hukum

Tanah Ulayat Atas Hak Guna Usaha, Soumatera Law Review, Volume 1, Nomor 1, 2018, 10.22216/soumlaw.v1i1.3384.

5 Danel Aditia Situngkir, Asas Legalitas Dalam Hukum Pidana Nasional Dan Hukum Pidana Internasional, Soumatera Law Review, Volume 1, Nomor 1, 2018, 10.22216/soumlaw.v1i1.3398. 
keterangan yang tertentu; dan 4) Cara hidup dan kesusilaan saksi serta segala sesuatu yang pada umumnya dapat mempengaruhi dapat tidaknya keterangan itu dipercaya. Dalam proses pengungkapan kasus pidana mulai dari tahap penyelididkan sampai dengan tahap pembuktian di persidangan, keberadaan dan peran saksi sangatlah penting. Keterangan saksi bisa menjadikan factor penentu dalam pengungkapan kasus piudana tersebut. Agar tuntutan jaksa dan rasa keadilan masyarakat dapat terpenuhi, maka semua pihak terutama aparat hukum harus sepakat bahwa saksi harus dilindungi terutama saksi pelapor, ini penting karena tujuan untuk menegakkan hukum dan keadilan dalam masyarakat. Pentingnya peranan saksi dalam proses peradilan pidana telah ditegaskan dalam ketentuan Pasal 184 sampai dengan Pasal 185 KUHAP.

Pentingnya menghadirkan seorang saksi kehadapan aparat penegak hukum khususnya pada tingkat penyidikan untuk dapat memberikan jaminan terungkapnya kasus peristiwa pidana walaupun bbukan bersifat mutlak. Pentingnya keterangan seorang saksi sebagai alat bukti yang sah sesuai dengan ketentuan pasal 184 KUHAP, oleh sebab itu keberadaan seorang saksi perlu mendapat perlindungan hukum di tengah masyarakat khususnya dalam kasus tindak pidana. ${ }^{6}$ Perlindungan saksi dan korban tidak lain merupakan penghormatan dan penghargaan atas possisi saksi dan korban sdalam suatu perkara. Di Indonesia hal ini sebenarnya sudah ada diatur dalam Undang-Undang Nomor 26 Tahun 2002 Tentang Pengadilan HAM dan kemudian diatur lebih lanjut dalam Peraturan Pemerintah Nomor 2 Tahun 2002 Tentang Cara Perlindungan terhadap Korban dan Saksi dalam Pelanggaran berat HAM. Ketentuan yang dimuat dalam undang-undang tersebut masih bersifat parsial tidak universal untuk semua perkara kejahatan. Oleh sebab itu diundangkanlah Undang-Undang Nomor 13 Tahun 2006 tentang Perlindungan saksi dan korban pada tanggal 11 Agustus Tahun 2006, sebagai jawaban terhadap permasalahan yang timbul untuk menyampaikan keterangan saksi ke hadapan pejabat yang berwenang untuk meminta keterangannya.

\section{B. METODE PENELITIAN}

Penelitian ini bertujuan untuk memenuhi kebutuhan terhadap objek penulisan atau suatu karya ilmiah guna mendapatkan data-data, pokok-pokok pikiran, serta pendapat lainnya dari pakar atau media apapun, yaitu terkait

6 Rianda Prima Putri, Pemeriksaan Penggabungan Gugatan Ganti Kerugian Dalam Perkara Pidana Di Pengadilan Negeri Kelas $1 B$ Bukittinggi, Soumatera Law Review, Volume 1, Nomor 1, 2018, 10.22216/soumlaw.v1i1.3348. 
pemeriksaan saksi dalam perkara pidana berdasarkan ius contitum indonesia. Dalam hal ini penulis memerlukan suatu metode yang berfungsi sebagai pedoman dalam pelaksanaan penelitian. Dalam pengumpulan bahan atau materi, didasarkan pada penelitian hukum normatif. ${ }^{7}$

\section{HASIL DAN PEMBAHASAN}

1. Pengertian Tentang Sistem Pembuktian

Sistem merupakan keseluruhan yang terdiri dari bagian-bagian yang mempunyai hubungan fungsional, baik antra bagianbagian yang akibatnya jika salah satu bagian tidak bekerja dengan baik akan mempengaruhi terhadap keseluruhannya itu. Jika dihubungkan dengan pengertian sistem peradilan pidana maka sistem peradilan pidana adalah sistem dalam masyarakat untuk menanggulangi masalah kejahatan. Menanggulangi diartikan sebagai mengendalikan kejahatan agar berada dalam batas-batas toleransi masyarakat. Setiap komponen yang tergabung dalam sistem peradilan pidana seperti kepolisian, kejaksaan, pengadilan dan pemasyarakatan titik sentralnya adalah memeriksa dan menyelesaikan kasus tindak pidana harus memahami manusia dan kemanusian yang wajib dilindungi harkat dan martabatnya

\footnotetext{
7 Laurensius Arliman S, Peranan Metodologi Penelitian Hukum di Dalam Perkembangan Ilmu Hukum di Indonesia, Soumatera Law Review, Volume 1, Nomor 1, 2018. http://doi.org/10.22216/soumlaw.v1i1.3346.
}

sebagai manusia. ${ }^{8}$ Sekalipun kita tahu bahwa tujuan tindakan penegakkan hukum adalah untuk mempertahankan dan melindungi kepentingan masyarakat. Penegakkan hukum tidak boleh mengorbankan hak dan martabat terdakwa/tersangka dan saksi.

Pembuktian adalah menyajikan faktafakta yang cukup menurut hukum untuk memberikan kepastian kepada majelis hakim mengenai terjadinya peristiwa atau hubungan.

Membuktikan adalah meyakinkan hukum tentang kebenaran dalil atau dalildalil yang ditemukan dalam suatu persengketaan. Lebih lanjut dikatakan bahwa pembuktian itu hanyalah diperlukan dalam persengketaan atau perkara dimuka hakim atau pengadilan. Kemudian menurut Sudikno Mertokusumo menerangkan bahwa pembuktian mengandung beberapa pengertian yaitu arti logis, konvensional dan yuridis. Membuktikan dalam arti logis adalah memberikan kepastian dalam arti mutlak, karena berlaku bagi setiap orang dan tidak memungkinkan adanya bukti lawan. Untuk membuktikan dalam arti konvensional disinipun membuktikan berarti juga memberikan kepastian nisbi atau relatif sifatnya. Membuktikan dalam

\footnotetext{
${ }^{8}$ Muhammad Afif, Penemuan Hukum Oleh Hakim Terhadap Kasus Carok Akibat Sengketa Tanah Dalam Masyaraka Madura, Soumatera Law Review, Volume 1, Nomor 2, 2018, 10.22216/soumlaw.v1i2.3714.
} 
arti yuridis berarti member dasar yang cukup kepada hakim yang memeriksa perkara dimuka persidangan atau pengadilan untuk memberikan dasar keyakinan bagi hakim tentang kepastian kebenaran suatu peristiwa yang terjadi.

Hukum pembuktian adalah merupakan sebagian dari hukum acara pidana yang mengatur macam-macam alat bukti yang sah menurut hukum. Sistem yang dianut dalam pembuktian, syaratsyarat dan tata cara mnegajukan bukti tersebut serta kewenangan hakim untuk menerima, menolak dan menilai suatu pembuktian. ${ }^{9}$ Tujuan pembuktian adalah untuk memperoleh kepastian bahwa suatu peristiwa atau fakta yang diajukan itu benar-benar terjadi guna mendapatkan keputusan yang benar-benar dan adil. Hakim tidak dapat menjatuhkan keputusan sebelum nyata baginya bahwa fakta atau peristiwa yang diajukan itu benar-benar. ${ }^{10}$ Pembuktian merupakan tindakan penting yang dalam meyelesaikan perkara di pengadilan baik perkara perdata maupun perkara pidana. Hakim dalam mengadakan

\footnotetext{
9 Rustan Sinaga, Peran Pengadilan Hubungan Industrial Pada Pengadilan Negeri Padang Kelas IA Dalam Memberikan Kepastian Hukum Terhadap Perkara Pemutusan Hubungan Kerja, Soumatera Law Review, Volume 1, Nomor 2, 2018, 10.22216/soumlaw.v1i2.3528.

${ }^{10}$ Miszuarty Putri, Pelaksanaan Restitusi Bagi Anak Yang Menjadi Korban Tindak Pidana Sebagai Bentuk Pembaruan Hukum Pidana Berdasarkan Peraturan Pemerintah Nomor 43 Tahun 2017, Soumatera Law Review, Volume 2, Nomor 1, 2019, 10.22216/soumlaw.v2i1.3567.
}

penilaian terhadap pembuktian harus berdasarkan pada peraturan perundangundangan yang mengatur tentang pembuktian tersebut. Adanya pembuktian itu bertujuan untuk menjamin keseimbangan dalam pembebanan alat bukti.

Sekalipun suatu peristiwa yang terjadi telah diajukan pembuktiannya, namun pembuktian itu harus dinilai oleh hakim. Dalam hal ini pembentuk undang-undang dapat mengikat hakim pada alat-alat bukti tertentu, sehingga ia bebas menilainyanya. Sebaliknya pembentuk undang-undang dapat menyerahkan dan member kebebasan kepada hakim dalam menilai pembuktian. ${ }^{11}$ Dalam hal menilai pembuktian, apakah hakim dapat bertindak bebas atau diikat oleh undang-undang, maka ada tiga teori dalam pembuktian ini yaitu: a) teori pembuktian bebas, yaitu teori ini menghendaki kebebasan yang seluasluasnya bagi hakim di dalam menilai alat bukti. Hakim tidak terikat oleh suatu ketentuan hukum atau setidak-tidaknya, ikatan-ikatan oleh suatu ketentuan hukum harus diatasi seminimum mungkin. Menghendaki kebebasan yang luas berarti menaruh kepercayaan bagi hakim untuk bersikap penuh tanggung jawab, jujur tidak memihak. Bertindak dengan keahlian dan

11 Laurensius Arliman S, Penegakan Hukum dan Kesadaran Masyarakat, (Yogyakarta: Deepublish, 2015), hlm. 67. 
tidak terpengaruh oleh apapun dan oleh siapapun; b) teori pembuktian negatif, dalam teori pembuktian negative, menghendaki supaya hakim dibatasi tindakan-tindakan di dalam memperolehdan menilai alat bukti. Harus ada ketentuan yang mengikat bagi hakim yaitu melarang tindakan-tindakan tertentu yang berhubungan dengan pembuktian. Jadi hakim dilarang dalam pengecualian; dan c) teori pembuktian terbatas positif, bahwa disamping adanya larangan bagi hakim, teori ini menghendaki ketentuan hukum yang bersifat positif yang mewajibkan hakim melakukan tindakan tertentu.

Apabila dalam praktek menemui kesulitan dalam penerapannya atau mempunyai kekurangan atau untuk memenuhi kebutuhan maka dipergunakanlah doktrin atau yurisprudensi. $^{12}$ alat bukti adalah segala sesuatu yang ada hubungannya dengan suatu perbuatan dimana dengan alat-alat bukti tersebut, dapat digunakan sebagai beban pembuktian guna menimbulkan keyakinan hakim untuk membenarkan adanya suatu tindak pidana yang telah dilakukan oleh terdakwa. Sistem pembuktian adalah pengaturan tentang macam-macam alat bukti yang boleh dipergunakan, penguraian alat bukti dengan

${ }^{12}$ Laurensius Arliman S, Ilmu PerundangUndangan Yang Baik Untuk Negara Indonesia, (Yogyakarta: Deepublish, 2019), hlm. 78. cara-cara bagaimana alat bukti tersebut dipergunakan dan dengan cara bagaimana hakim dalam mebentuk keyakinananya. ${ }^{13}$ Tujuan dan guna pembuktian bagi para pihak yang terlibat dalam proses pemeriksaan persidangan adalah: a) Bagi penuntut umum, pembuktian adalah merupakan usaha untuk meyakinkan hakim yaitu berdasarkan alat bukti yang ada, agar menyatakan seorang terdakwa bersalah sesuai dengan surat atau catatan dakwaan; b) Bagi terdakwa atau penasehat hukum, pembuktian merupakan usaha sebaliknya, untuk meyakinkan hakim yaitu berdasarkan alat bukti yang ada agar menyatakan terdakwa atau penasehat hukum jika mungkin harus mengajukan alat-alat bukti yang menguntungkan atau meringankan pihaknya. Biasanya bukti tersebut disebut bukti kebalikan; dan c) Bagi hakim, atas dasar pembuktian tersebut yaitu dengan adanya alat-alat bukti dipersidangan baik yang berasal dari penuntut umum atau penasehat hukum/terdakwa dibuat dasar untuk membuat keputusan.

Pada dasarnya seluruh kegiatan dalam penyelesaian perkara pidana, sejak penyidikan sampai putusan akhir diucapkan dimuka persidangan oleh majelis hakim adalah berupa kegiatan yang berhubungan

${ }^{13}$ Laurensius Arliman S, Danel Situngkir, Rianda Putri, Rahmat Fauzi, Hariyadi, Gokma Toni Parlindungan S, Cyber Bullying Against Children In Indonesia, International Conference on Social Sciences, Humanities, Economics and Law; Padang, 2018. DOI:10.4108/eai.5-9-2018.2281372. 
dengan pembuktian atau kegiatan untuk membuktikan. Walaupun hukum pembuktian perkara pidana terfokus pada proses kegiatan pembuktian di sidang pengadilan, tetapi sesungguhnya proses membuktikan sudah ada dan mulai pada saat penyidikan, suatu pekerjaan awal dalam menjalankan proses perkara pidana oleh negara. Mencari bukti sesungguhnya adalah mencari alat bukti, karena alat bukti tersebut hanya dapat diperoleh dari alat bukti termasuk barang bukti. ${ }^{14}$ Bukti yang terdapat pada alat bukti tersebut kemudian dinilai oleh para pejabat puntuk menarik kesimpulan, apakah bukti yang ada itu menggambarkan suatu peristiwa yang diduga tindak pidana atau tidak. Bagi penyidik, bukti yang didapat dari alat bukti tersebut dinilai untuk menarik kesimpulan, apakah dari bukti yang ada itu sudah cukup untuk membuat terang tindak pidana yang terajadi dan sudah cukup dapat dipergunakan untuk menemukan tersangka.

2. Keterangan Saksi, Keterangan Ahli, Surat, Petunjuk, Keterangan Terdakwa Undang-undang menetapkan beberapa ketentuan mengenai alat bukti "kesaksian" untuk mendekati kebenaran. Tidak memenuhi ketentuan ini berarti tidak adapatnya kesaksian itu dipergunakan

14 Laurensius Arliman S, Analisis Dari Perspektif Politik Hukum Terhadap Pasal 56 Undang-Undang Nomor 8 Tahun 1981 Tentang Kitab Undang Undang Hukum Acara Pidana, Lex Jurnalica, Volume 15, Nomor 3, 2018. sebagai bukti. Kterangan saksi sebagi alat bukti adalah apa yang saksi nyatakan didepan sidang pengadilan. Dalam pasal 185 ayat (1) KUHAP menyatakan bahwa, keterangan seorang saksi saja tidak cukup untuk membuktikan bahwa terdakwa bersalah terhadap perbuatan yang didakwakan kepadanya. ${ }^{15}$ Dengan lain perkataan, hakim pengadilan negeri tidak boleh menjatuhkan hukuman pidana kepada terdakwa, jika terdakwa mungkir kesalahannyadan hanya ada seorang saksi saja yang memberatkan terdakwa, sedangkan alat bukti lain tidak ada. Ini tidak berarti bagi tiap-tiap peristiwa dari tuduhan harus ada dua orang saksi. ${ }^{16}$ Minimum dua saksi diharuskan untuk tuduhan seluruhnya.

Keterangan beberapa orang saksi yang bediri sendiri-sendiri tentang suatu kejadian atau keadaan adapat digunakan sebagai suatu alat bukti yang sah apabila keterangan saksi itu ada hubungannya satu dengan yang lainnya sedemikian rupa, sehingga dapat dibenarkan adanya suatu kejadian atau keadaan tertentu. ${ }^{17}$ Dalam menilai kebenaran keterangan seorang

15 Laurensius Arliman S, Notaris dan Penegakan Hukum Oleh Hakim, (Yogyakarta: Deepublish, 2015), hlm. 23.

${ }^{16}$ Gokma Toni Parlindunga S, Laurensius Arliman S, Politik Hukum Perlindungan Anak, (Yogyakarta: Deepublish, 2017), hlm. 41.

${ }^{17}$ Laurensius Arliman S, Perlindungan Hak Anak Yang Berhadap Dengan Hukum Di Wilayah Hukum Polisi Resort Kota Sawahlunto, Lex Jurnalica, Volume 14, Nomor 2, 2018. 
saksi, hakim harus dengan sungguhsungguh memperhatikan: a) Persesuaian antara keterangan saksi satu dengan yang lain; b) Persesuaian antara keteranagn saksi dengan alat bukti lain; c) Alasan yang mungkin dipergunakan oleh saksi untuk memberikan keterangan tertentu; d) Cara hidup saksi dan kesusilaaan saksi serta segala sesuatu yang pada umumnya dapat mempengaruhi dapat tidaknya keterangan itu dipercaya (Pasal 185 ayat 6 KUHAP).

Keterangan saksi yang tidak disumpah meskipun sesuai satu dengan yang lainnya, tidak merupakan alat bukti , namun apabila keterangan itu sesuai dengan keterangan dari saksi yag disumpah maka dapat dipergunakan sebagai tanbahan alat bukti sah yang lain (Pasal 185 ayat 7 KUHAP).

Apabila kita perhatikan dengan seksama pasal-pasal yang mengatur tentang keterangan ahli kemudian kita hubungkan anatara pasal yang satu dengan pasal yang lainnya maka dapat dibedakan sebagai berikut: a) Keterangan ahli yang dimaksud dalam Pasal 1 angka 28 adalah pengertian keterangan ahli secara umum. Jadi meliputi keterangan ahli yang diberikan dihadapan penyidik, dan keterangan ahli yang diberikan secara tertulis atas permintaan tertulis dari penyidik; b) Keterangan ahli yang dimaksud dalam pasal 120 KUHAP yaitu pendapat orang ahli yang diberikannya dalam pemeriksaan yang dilakukan oleh penyidik. Keterangan tersebut diberikan dibawah sumpah dan dicatat oleh penyidik dalam berita acara pemeriksaan ahli; c) Keterangan ahli yang dimaksud dalam pasal 133 KUHAP adalah keterangan tertulis yang diberikan oleh ahli atas permintaan tertulis dari penyidik. Keterangan ahli yang demikia dalam praktek disebut sebagai visum et refertum; dan d) Keterangan ahli yang dimaksud dalam Pasal 186 KUHAP adalah keterangan ahli yang diberikan oleh seorang ahli dalam persidangan dan dibawah sumpah. Keterangan ahli yang demikianlah yang dimaksud dalam Paal 184 ayat 1 huruf b sebagai salah satu alat bukti yang sah.

Keterangan terdakwa tidak diatas sumpah, dapat dianggap, hal ini memberikan keleluasan padanya memberikan keterangan-keterangan dengan tidak menghiraukan factor kebenaran dan hanya berpedoman pada kepentingan baginya, dengan dibatasi oleh pertimbangan-pertimbangan dapat tidaknya keterang itu diterima akal. ${ }^{18}$ Oleh karena itu bilamana keterangan-keterangan dimaksud sebagai mengentengkan tidak dapat diterima akal, maka keterangan itu sebaliknya menjadi memberatkan. Suatu pengakuan baru dapat mempunyai daya

18 Tommy Busnarma, Penerapan Sanksi Pidana Denda Terhadap Pelaku Tindak Pidana Penyalahgunaan Dan Peredaran Gelap Narkotika Di Pengadilan Negeri Padang, Soumatera Law Review, Volume 2, Nomor 1, 2019, 10.22216/soumlaw.v2i1.3559. 
bukti cukup bila disertai: a) diucapkan di muka hakim dalam sidang; dan b) keterangan yang jelas tentang kedaan dalam mana semua atau sebagian harus cocok dengan keterangan si korban. Keterangan adalah apa yang dinyatakan oleh terdakwa dipersidangan yang ia lakukan atau ia ketahui sendiri atau alami sendiri.

Saksi adalah orang yang dapat memberikan keterangan guna kepentingan penyidikan, penuntutan dan peradilan tentang suatu perkara pidana yang ia dengar sendiri, ia lihat sendiri dan ia alami sendiri. Keterangan saksi adalah salah satu alat bukti dalam perkara pidana yang berupa keterangan dari saksi mengenai suatu peristiwa pidana yang ia alami sendiri, lihat sendiri dengan menyebutkan alasan dari pengetahuannya itu. Dengan demikian pandangan atau rekaan yang diperoleh dari hasil pemeriksaan saja bukan merupakan keterangan saksi. Dengan kesaksian dalam hukum acara pidana adalah apa yang ia alami sendiri oleh saksi dalam peristiwa itu. Dapat juga dikatakan apa yang ditangkap oleh panca indranya yang meliputi apa yang ia lihat dengan matanya, bukan apa yang ia lihat dengan batinnya, apa yang di dengar dari telinganya atau apa yang dicium dari hidungnya, apa yang dirasa dari perasaannya bukan apa yang dirasa menurut anggapannya atau perasaannya dan apa yang dirasa dengan lidahnya.
Untuk dapat menjadi saksi maka harus dipenuhi syarat-syarat antara lain: a) Syarat formil yaitu: a) berumur 15 tahun keatas; b) sehat akalnya; c) tidak ada hubungan keluarga sedarah dan semenda dari salah satu pihak menurut keturunan yang lurus kecuali undang-undang menentukan lain; d) tidak dalam hubungan perkawinan dengan salah satu pihak meskipun sudah bercerai; e) tidak ada hubungan kerja dengan salah satu pihak dengan menrima upah kecuali undangundang menentukan lain; f) menghadap di persidangan; g) mengangkat sumpah sesuai dengan agamanya; h) sekurang-kurangnya 2 orang untuk kesaksian suatu peristiwa atau dikuatkan dengan bukti lain; dan i) dipanggil masuk ke ruang sidang dan memberikan keterangan secara lisan.

Kesaksian merupakan kepastian yang diberikan kepada hakim dipersidangan tentang peristiwa pidana atau peristiwa perdata yang terjadi dengan pemberitahuan secara lisan dan pribadi oleh orang yang bukan salah satu pihak dalam perkara pidana atau perdata yang dipanggil dipersidangan. Jadi keterangan yang diberikan oleh saksi adalah benar-benar kejadian yang dialami sendiri, sedangkan pendapat atau dugaan yang diperoleh secara berfikir tidaklah merupakan kesaksian. Jenis-jenis saksi yaitu: a) Saksi biasa, yaitu kesaksian yang diberikan oleh orang umum yaitu orang yang melihat, 
mendengar dan mengalami sendiri peristiwa yang disengketakan; b) saksi ahli, yaitu seorang yang mempunyai pengetahuan dan keahlian khusus mengenai sesuatu yang menjadi sengketa yang membeikan penjelasan dan bahan baru bagi hakim dalam memutuskan perkara.

Disamping saksi biasa maka saksi dapat dibedakan berdasarkan status dalam tindak pidana yaitu: a) saksi pelapor/korban, adalah mereka yang karena sesuatu alasan menyampaikan laporan/pengaduan atau yang mengaku telah menjadi korban suatu peristiwa yang diduga sebagai tindak pidana, yang karenanya dengan dilandasi berbagai kemungkinan motivasi melaporkan peristiwa tersebut kepada pihak yang berwenang. Saksi pelapor diduga memiliki beberapa kelebihan disbanding saksi biasa, makanya darinya perlu digali kesaksian yang dimilikinya.

Penetapan seorang tersangka untuk dijadikan saksi merupakan upaya terakhir, apabila memang untuk diketemukan saksisaksi lain yang secara langsung melihat, mendengar atau mengalami sendiri kejahatan tersebut. Berdasarkan bobot keterangannya maka saksi dapat dibedakan: ${ }^{19}$ a) saksi yang dapat dipercaya, yaitu mereka yang memiliki kepribadian

19 Sudikno Mertokusumo, Mengenal Hukum: Suatu Pengantar, (Yogyakarta: Liberty, 2003), hlm. 70. yang stabil, memberikan keterangan dengan dukungan bukti, pengetahuan yang baik dan petunjuk lainnya serta tidak ada kepentingan baik langsung maupun tidak langsung dengan tindak pidana yang terjadi; b) saksi yang meragukan adalah mereka yang menyampaikan keterangan yan terdapat beberapa kejanggalan dan perbedaan satu sama lain serta tidak sepe nuhnya didukung dengan bukti yang lain; c) saksi yang berbohong adalah mereka yang menyampaikan keterangan yang tidak dapat dipercaya karena keterangannya tidak logis serta bertentangan satu sama lain; d) saksi yang pandai meyakinkan adalah mereka yang dalam memberikan keterangannya mempergunakan kata-kata tertentu dengan harapan dapat meyakinkan pemeriksa.

\section{Kekuatan Hukum Saksi di Depan Pengadilan}

Apabila saksi telah memenuhi syarat formal dan materil maka ia mempunyai nilai pembuktian bebas. Hakim bebas untuk menilai kesaksian itu sesuai dengan hati nuraninya. Hakim tidak terikat dengan keterangan saksi. Hakim dapat menyingkirkan asal dipertimbangkan dengan cukup berdasarkan argumentasi yang kuat. Agar keterangan saksi dapat digunakan sebagai bukti, majelis hakim perlu mempercayai kebenaran keterangan saksi dengan memperhatikan cara hidup dan saksi, adat istiadat dan martabat saksi serta segala hal yang menyebabkan saksi 
dapat dipercaya. Jadi majelis hakim harus memperhatikan segala yang mungkin mempengaruhi sikap saksi dan apa yang mendorong saksi untuk menerangkan demikian.

Keterangan seorang saksi tanpa alat bukti lainnya tidak dianggap sebagai pembuktian yang cukup. Seorang saksi bukan saksi (unus testis nullus testis). Kekuatan pembuktian dari kesaksian seseorang saksi saja tidak boleh dianggap sempurna oleh hakim melainkan hanya bernilai sebagai bukti permulaan. Oleh karena itu harus disempurnakan dengan alat bukti lain. Apakah 2 (dua) orang saksi atau lebih yang member keterangan tentang kejadian berlainan merupakan unus testis?

Keterangan saksi-saksi yang jika dihubungkan satu sama lain mempunyai arti dan maksud yang sama dapat menghasilkan bukti sah dan sempurna. Jadi penilaian beberapa saksi yang masing-masing bediri sendiri dan terpisah satu sama lain tentang berbagai peristiwa yang digunakan untuk membuktikan suatu perbuatan diserahkan pada pertimbangan hakim. Awal suatu rangkaian proses peradilan pidana diawali dengan proses penyelidikan. Hal ini penting untuk dilakukan agar aparat hukum terkait terhindar dari kesalahan yang bukan wewenangnya.

Ada beberapa wewenang yang dimiliki oleh penyidik adalah : Menerima laporan atau pengaduan dari seseorang adanya suatu tindak pidana, Melakukan tindakan pertama pada saat ditempat kejadian, Menyuruh berhenti seorang tersangka dan memeriksa tanda pengenal tersangka, Melakukan penangkapan, penahanan, penggeledahan dan penyitaan, Melakukan pemeriksaan dan penyitaan surat, Mengambil sidik jari dan memotret seseorang, Memanggil orang untuk didengar dan diperiksa sebagai tersangka atau saksi, Mendatangkan seorang ahli yang diperlukan dalam hubungan nya dengan pemeriksaan perkara, Mengadakan penghentian penydikan. Mengadakan tindakan lain menurut hukum yang bertanggung jawab,

Berita acara yang berisi keterangan saksi ditanda tangani oleh penyidik dan saksi. Dalam penanda tanganan berita acara pemeriksaan setelah lebih dahulu isi berita: a) saksi menanda tangani berita acara pemeriksaan setelah lebih dahulu isi berita acara tersebut disetujuinya. Apakah persetujuan itu diberikan setelah dibacakan lebih dahulu oleh penyidik dihadapannya atau penyidik menyuruh untuk membaca sendiri. Sebenarnya cara kedua yang terbaik, jika saksi pandai membaca. Tetapi kalau ia tidak pandai membaca tidak ada pilihan lain selain daripada membacakan berita acara dihadapan saksi oleh penyidik; b) undang-undang memberikan kemungkinan kepada saksi tidak menanda tangani berita acara pemeriksaan. Jika saksi 
tidak mau membubuhkan tanda tangan dalam berita acara pemeriksaan, penyidik membuat catatan tentang ketidakmauan itu dalam berita acara. Catatan tersebut berupa penjelasan alasan yang menjadi sebab saksi menolak membubuhkan tanda tangan dalam berita acara dengan penjelasan Pasal 118 ayat 2 KUHAP hanya bersifat umum yang berbunyi : "Dalam hal saksi tidak mau menanda tangani berita acara ia harus member alasan yang kuat". ${ }^{20}$ Melihat penjelasan ini, bukan semakin memperjelas alasan penolakan, tetapi semakin kabur, sebab penjelasan itu hanya merupakan penekanan pada kualitas alasan, namun tidak memerinci alasan sendiri. Barangkali satu-satunya alasan yang paling relevan dalam penolakan tersebut, apabila saksi berpendapat apa yang tertulis dalam berita acara pemeriksaan tidak bersesuaian dengan maksud dan kebenaran keterangan yang diberikan. Atau isi berita jelas-jelas bertentangan dan berbeda dengan keterangan yang diberikan atau berdasarkan paksaan atau intimidasi.

Keterangan saksi dalam persidangan sangat dibutuhkan karena: 1) Saksi sangat menentukan dalam proses tindak pidana karena dengan keterangan saksi dapat membuat terang suatu tindak pidana. Sekalipun aparat hukum sudah mendapat

20 Satjipto Rahardjo, Hukum Progressive (Penjelajahan Suatu Gagasan). (Jakarta: Majalah Hukum Newsletter No. 59 Desember 2004. Yayasan Pusat Kajian Hukum), hlm. 67. dua alat bukti yang cukup untuk menjerat seorang tersangka pelaku tindak pidana. Jika dua alat bukti tersebut tidak ada keterangan seorang saksi, maka aparat hukum masih belum merasa sempurna dalam pemberkasan perkara karena alat bukti tanpa keteranagan saksi dapat saja kurang meyakinkan hakim dalammenjatuhkan putusan. Karena sedemikian pentingnya peranan seorang saksi dalam mengungkap kasus tindak pidana maka aparat terkait berusaha secara makismal untuk meberikan perlindungan terhadap seorang saksi sebagaimana yang dimaksud oleh KUHAP; dan 2) Saksi dapat memberikan petunjuk yang lebih nyata untuk mengungkap kasus tindak pidana, karena dengan keterangan yang diberikan oleh seorang saksi, aparat hukum dapat mempertimbangkan kasus berdasarkan indikator-indikator yang didapatkan dari saksi.

\section{PENUTUP}

Dari uraian yang dikemukakan diatas maka dapat diambil kesimpulan, bahwa Proses pemeriksaan saksi dimulai dari penyidikan sampai pada tingkat penuntutan di pengadilan. Di tingkat penyidikan maka terlebih dahulu saksi diperiksa oleh penyidik dengan memperhatikan perlindungan terhadap saksi yaitu tanpa ancaman atau tekanan.dari pihak manapun. Kemudian saksi dapat diperiksa di tempat kediaman saksi dan saksi diperiksa tanpa 
disumpah. Sedangkan pada tingkat penuntutan atau pesidangan maka terlebih dahulu saksi dipanggil untuk didengar keterangannya. Kemudian saksi ditanyakan oleh hakim tentang identitasnya serta kemudian saksi disumpah. Atas keterangan saksi maka para pihak dapat memberikan keberatannya atau penyangkalan terhadap keterangan saksi. Setelah didengar keterangan saksi dan dihubungkan dengan alat bukti lain maka hakim akan memberikan penilaian terhadap keterangan

\section{DAFTAR PUSTAKA}

Ahmad Rifai, Penemuan Hukum oleh Hakim dalam Perspektif Hukum Progesif, (Jakarta: Sinar Grafika, 2010).

Danel Aditia Situngkir, Asas Legalitas Dalam Hukum Pidana Nasional Dan Hukum Pidana Internasional, Soumatera Law Review, Volume 1, Nomor 1, 2018, 10.22216/soumlaw.v1i1.3398.

Gokma Toni Parlindunga S, Laurensius Arliman S, Politik Hukum Perlindungan Anak, (Yogyakarta: Deepublish, 2017).

Jasmir, Pengembalian Status Hukum Tanah Ulayat Atas Hak Guna Usaha, Soumatera Law Review, Volume 1, Nomor 1, 2018, 10.22216/soumlaw.v1i1.3384.

Laurensius Arliman S, Penegakan Hukum dan Kesadaran Masyarakat, (Yogyakarta: Deepublish, 2015).

Laurensius Arliman S, Reformasi Penegakan Hukum Kekerasan Seksual Terhadap Anak Sebagai Bentuk Perlindungan Anak Berkelanjutan, Kanun Jurnal Ilmu Hukum, Volume 19, Nomor 2, 2017. saksi apakah keterangan saksi itu dapat dipercaya atau tidak, Pertimbangan dalam menilai keterangan saksi antara lain adalah apabila terdapat persesuaian antara keterangan saksi yang satu dengan keterangan saksi yang lain.adanya keterangan saksi dengan alat bukti yang lainnya, segala sebab tentang tentang pengetahuan saksi menerangkan tentang duduknya perkara pidana, tentang apa yang ia lihat, ia dengar atau yang ia alami sendiri.serta cara hidup dan kesusilaan saksi

Laurensius Arliman S, Notaris dan Penegakan Hukum Oleh Hakim, (Yogyakarta: Deepublish, 2015).

Laurensius Arliman S, Peranan Metodologi Penelitian Hukum di Dalam Perkembangan Ilmu Hukum di Indonesia, Soumatera Law Review, Volume 1, Nomor 1, 2018. http://doi.org/10.22216/soumlaw.v1i 1.3346.

Laurensius Arliman S, Analisis Dari Perspektif Politik Hukum Terhadap Pasal 56 Undang-Undang Nomor 8 Tahun 1981 Tentang Kitab Undang Undang Hukum Acara Pidana, Lex Jurnalica, Volume 15, Nomor 3, 2018.

Laurensius Arliman S, Perlindungan Hak Anak Yang Berhadap Dengan Hukum Di Wilayah Hukum Polisi Resort Kota Sawahlunto, Lex Jurnalica, Volume 14, Nomor 2, 2018.

Laurensius Arliman S, Ilmu PerundangUndangan Yang Baik Untuk Negara Indonesia, (Yogyakarta: Deepublish, 2019).

Laurensius Arliman S, Danel Situngkir, Rianda Putri, Rahmat Fauzi, Hariyadi, Gokma Toni Parlindungan S, Cyber Bullying Against Children 
In Indonesia, International Conference on Social Sciences, Humanities, Economics and Law; Padang, 2018. DOI:10.4108/eai.5-92018.2281372.

Laurensius Arliman S, Surat Dakwaan dalam Hukum Acara Pidana Sebagai Bentuk Mendukung Penegakan Hukum di Indonesia, Kosmik Hukum, Volume 19, Nomor 2019, https://doi.org//10.30595/kosmikhuk um.v19i1.4081.

Miszuarty Putri, Pelaksanaan Restitusi Bagi Anak Yang Menjadi Korban Tindak Pidana Sebagai Bentuk Pembaruan Hukum Pidana Berdasarkan Peraturan Pemerintah Nomor 43 Tahun 2017, Soumatera Law Review, Volume 2, Nomor 1, 2019, 10.22216/soumlaw.v2i1.3567.

Moeljatno, Asas-Asas Hukum Pidana, (Jakarta: PT Rineka Cipta, 2002.

Muhammad Afif, Penemuan Hukum Oleh Hakim Terhadap Kasus Carok Akibat Sengketa Tanah Dalam Masyaraka Madura, Soumatera Law Review, Volume 1, Nomor 2, 2018, 10.22216/soumlaw.v1i2.3714.

Rianda Prima Putri, Pemeriksaan Penggabungan Gugatan Ganti Kerugian Dalam Perkara Pidana Di Pengadilan Negeri Kelas $1 B$ Bukittinggi, Soumatera Law Review, Volume 1, Nomor 1, 2018, 10.22216/soumlaw.v1i1.3348.

Rustan Sinaga, Peran Pengadilan Hubungan Industrial Pada Pengadilan Negeri Padang Kelas IA Dalam Memberikan Kepastian Hukum Terhadap Perkara Pemutusan Hubungan Kerja, Soumatera Law Review, Volume 1, Nomor 2, 2018, 10.22216/soumlaw.v1i2.3528.

Sajtipto Rahardjo, Penafsiran Hukum Yang Progresif dalam Antony Freddy Susanto, Semiotika Hukum : Dari Dekonstruksi Teks Menuju
Progresifitas Makna, (Bandung: Refika Aditama, 2005).

Satjipto Rahardjo, Hukum Progressive (Penjelajahan Suatu Gagasan). (Jakarta: Majalah Hukum Newsletter No. 59 Desember 2004. Yayasan Pusat Kajian Hukum).

Sinta Agustina, Asas Legalitas dalam Tindak Pidana Korupsi, (Padang: dalam seminar Azas Legalitas dan Penemuan Hukum yang diadakan oleh Hima Pidana Fakultas Hukum UNAND pada tanggal 25 Maret 2010).

Sudikno Mertokusumo, Mengenal Hukum: Suatu Pengantar, (Yogyakarta: Liberty, 2003).

Tommy Busnarma, Penerapan Sanksi Pidana Denda Terhadap Pelaku Tindak Pidana Penyalahgunaan Dan Peredaran Gelap Narkotika Di Pengadilan Negeri Padang, Soumatera Law Review, Volume 2, Nomor 2019, 10.22216/soumlaw.v2i1.3559. 